\title{
Postmodern Enslavement and Identityanomie: Analogue Modes of Escape from Freedom
}

\author{
Predrag Živković \\ Faculty of Philosophy-Nikšić \\ Obrad Samardžić \\ Faculty of Philosophy-Nikšić \\ Miomirka Lučić \\ Faculty of Philosophy-Nikšić
}

Doi:10.5901/jesr.2014.v4n4p408

\begin{abstract}
The paper puts special emphasis on issue resonances identity shaft, which in postmodern orbit is not conceptual "favorite" for inaugurisanost perception of reality and value structure. Notated perception of the postmodern era, its conceptual articulation seeks to review the traditional structure, the postulates of postmodernism, not more "staff" refers to the evolution of the product technological sphere. Recline on the philosophical background of Jean Baudrillard, the authors discuss the indicative field simulacrum who have no ontological potential and whose affirmative purpose of bringing man to the stage gnoseological passivity. Communication "binder " postmodernity, represents deprivation their own (human) authority as a subjective conviction and questioning the identity of belonging. Therefore, the sense of identity of the modern era is reflected in the fragmentation and fluidity of existence, and it is right to say that a man living in the modern era of floating universe, without a certain criteria. Continuous changes that accompany burdened life courses of individuals and apparently are presented as a privilege and needs actually are hidden mechanisms by which individuals are listed and seduced by easy consumption, obviate indirectly authenticity and originality of its own spirit. It's value skeleton is ideologically determined consumer orientation.
\end{abstract}

Keywords: identity, postmodernism, simulacrum, totalitarian conscience.

Before we start with the extraction and analysis of the most important characteristics of epochal datum - postmodernism, out of which we derive the theoretical construction post-postmodernism, which is by its intermediary character the field of implemented ideology, it is necessary to test the explicatory "presence" of the topic, on the crossroad of tradition and progress, with the latent danger of primordial blindness of traditionalism and those constellations of postmodernism which according to their dynamic of expansion indicate a mystified human biography. Without occupying the space for more specific aspects of theorising, we are going to focus on introducing a line of argumentations on the epochal datum. In the background of our reflective plea, we fixate the points where the creation of epochally general tone of postmodernism have occurred, which have enabled theoretical investment as an inherited epistemic paradigm, for the creation and transformation of the postmodern subjectivity structure, into something that cannot be considered as a human construction, but a quality mutation of the basic elements of the concept postmodernity - which is recognised as postpostmodernism. A great attraction of this theoretical commitment and epistemic detection of the epoch, certainly belongs to Zeljko Simic. Namely, in the massive description that is committed to the problem of totalitarian sense, pervaded through the society structure, sense and ego-conceptuality, as well as the ratiocentric tradition, Simic suggests, through the map of postmodernism trends, those spots where the post-postmodernism has profiled and identified epistemic principles of its discourse. The appropriation and adequacy of the questions on epochal datum, are confirmed by the response of post-postmodernism that suppresses and sanctions every speech of human practicality and deprives the dignity of, what was not so long ago considered as "human" and culture. Such a tendency can be easily spotted in Simioc's lines: ....post-postmodernism accomplishes such pseudo-ontological atmosphere where an individual withdraws from gnoseological initiative as a crucial immanent ingredient of his/her subjectivity. (Let's remind that this was preceded by a diametrical opposite, postmodern insistence on humouring omnipotence of beneficial - said in Bart's manner subject competence!). At the same time, this extirpation of natality itself is amortised by the illusion that a thing holding the initiative - technological universe - is exclusively realised due to consumer's participation in the transaction of modelled images. In short, post-postmodernity seems to be the transitional phase on the way from a complete transfer of 
competence of subject to the technological system, while the fact of a parallel human objectification stuns with a participative agitation, which in the roots dismisses gnoseological impulse. Let's emphasise: each portion of technological and mediatised post-postmodern reality is no longer placed - as in Baudrillard's simulacrums - in order to satisfy hypertrophic narcissistic desire of an omnipotent individual-subject, dissatisfied with unambiguous monotonously paved history and tradition". (Simic, 2012 a: VIII/XIX). According to author's culturological vocation, his intentional consideration of constitutive elements of human existence is justified, while searching the elements of non-afflicted identity axis. It is about sophisticated mutation of distinctive elements of identity that in post-postmodern surrounding lose their ontological valence, while ceding inherent share to the technological substrate, in the creation of valuative frame. It is easy to reason an indifference of technological imaginarium which does not wish to degrade human position but his sensible and ontological set - opinions, feelings and actions, altogether, and present itself as an autobiographer of a long ago forgotten cultural creation called human! Socially employable material, Simic finds in Jung's review of Joice's Ulysses: "Actually, Jung's review of Joice's Ulysses indicated postmodern paroxysm the best. Ulysses is cold, distanced observer that observes a swarm of trivial sensuous events in which he is involved, from the perspective of an omnipotent subject. One more, but by no means less important change, is consisted in the reduction of circulation rhythm: deprived of external actions and temptations, enclosed by uniformed notions, postmodern observer abides in ultimately restricted (diurnal) temporal surroundings but needed as such in order to meet for him severely impoverished diversity of affliction of intangible identity axis". (Ibid XIII). We are going to mark the last lines of structural changes. The thing that as a postpostmodern culture is imposed to the individual, is indeed, forcing the multitude of reflections of consumer corpus, and which aims to subjective self-recognition and installation into technological orbit. The essence is that a Western man handed contemplative and empathic powers to synergic terminal of technological requirements. The privilege and monopoly for the prophecy of postmodern destruction of the subject, certainly belong to Lyotard. Namely, even though he presented postmodernism through "a wide gate", by giving it the plausibility, when he realized its destructivity and production of uncertainty of human existence, terror of mobilization of all social classes for serving to, as Simic notices, technological knowledge, and which is a recapitulation of Nietzsche's defeatist vision of the existing values of civilization and culture, Lyotard newly "preached" about (post) postmodern discourse which became a meritorious center of norming identity structure. "Therefore, everything that surrounds and immediately enables a morning meal and hygiene of a modern Ulysess is, according to Lyotard, and the author is marking our location of the problem, the terror of technological knowledge installed as a polyp with exactly as many ingrowing ends as needed for the Ulysses to hermetically suppress each impression of an individual existence. Ulysses is a conductor, as well as air is. While eating, he is not feeding himself anymore, but an extension of a hidden plan. When starting his workday, he no longer enters the progress of humanity nor nirvana of expressing diversity, but a technological action whose autonomic powers has long ago fled from the domain of critical appellation against its own domicile cradle, even when overwhelmed with obsolete social invectives of humanists versus late capitalism, liberal democracy, new world order and similar. All of those in the essence socially manipulative techniques are anachronic. The modern Ulysses is not a slave of any concept, order or organization of people, but of a general inner contamination of mankind... Written in a typical "postmodern" non-binding tone, his (Lyotard's) work that we are dealing with, finishes the contextualization with a subjective opposition of the progress capacity - which is, actually, agreeable derivative of all that we have endeavored to fixate as a complete archeology of a ratiocentric tradition and alternative" (Ibid, 110-111). The list of analytical disputes with the epoch of post-postmodernism, Simic continues with merciless abrasions of "grimaces" of liberal capitalism. "A modern metamorphosis of capitalism has captured a former culture autonomy, pervaded it with a wrapped war for profit, and replaced it with a capital as the only social deferential. The abolition of the autonomic culture discourse signified an abolition of critical distance, hence the newly standardized product of an ideal cultural product became a unique mixture of culture and consumption: the cultural product is the one that induces consumption, and the life has become an infinite consummative consumption because this has become "cultural" " (Ibid, 156). The wholesome program concept of studying postmodern culture and a troublesome outcome of technological "dispute" with an axiological universe, we are going to intonate through the work of Ratko R. Bozovic "Life of the Culture" in which the author boldly researches the appearance of "the genuine myth", all with the aim to find a different meaning of life comparing to the existing objectification and alienation. Abandoning a vision of a sacral existence, the author provides temporal novum exegesis, where the former values continuum is simply amnestied over the progress ideology flurry, while the progress, and this is a G. Vattimo's completion of its semantic term, "is more and more shaped as a value itself" (Vattimo, 1991: 105). The only thought, as the author notices, which remains and deprives man of knowledge about axiological orbit, is the thought about technology. What is interesting in this study is applied sciences credibility abolition of a kind. In the sense of marked sententia, in today's boom of technological civilization and serial industrial production, a need for a pseudo world is imprinted into individual consciousness which relaxes and most recently achieves catharsis of the commonplace. The axis of genuine 
understanding of a human cannot be founded on ego-conceptuality. Ratiocentric orientation of the subject, had and has a completely different outcome and consequences to the civilization since the revelation in Decartes's formulations. Finally, what is happening viewed from the Heiddeger's depth of ontology of behavior, and who should this individual give their "attention" to? " .... human essence consists in them being more than a mare person if a mare person introduces themselves as an ingenious being. This "more" must not be understood as additive as if the traditional definition [a man as animal rationale - our supplement] of a man remains, however, fundamental, while only extended by the supplement of existential. "More" is with the meaning more genuine and therefore essentially more substantial. However, the riddle appears here: a human is thrown. This means: as an ek-sisting counter-throw of Being, human is more animal rationale insofar exactly less than a man understood on the foundations of subjectivity [our cursive]. The human is not the master of entities. It gains the essential poverty of the shepherd, whose dignity consists in being called by the Being itself into the preservation of Being's truth. The call comes as a throw from which the throwness of openness-for-Being derives. In his essential unfolding within the history of Being the human being is the entity whose being as ek-sistence consists in dwelling in the nearness of Being. The human being is the neighbour of Being. " (Heiddeger, 2003:304, taken from Simic, 2007b:222). It is not necessary to emphasise that the human cannot search their "Being justification" in technological actions and ratio-centricity, but from the completely different observing spot of the Being.

In order to neutralise the idea of society and avulse the Being from its roots, a market evolved into the merit of all sensibilities and temporality, or the last stronghold of the correspondent individuals whose thematic medium is - the consumption. The market becomes a paradigm of directed and controlled opinion, and its ideal type is an authentic consumer, whose barren identity is mirrored in the elevation to the statically unreachable ideal - mobilised consumer. Such a development is only a form of the Subject derangement. Instead of it, the artificial aggregate is formed, whose ultimate purpose of survival is to overpower the Other in consumption and consummation.

In a modern world of simulacrums, as Baudrillard addresses it, our "human centre" is not positioned in ourselves, but dislocated and abandoned for the exterior authoritarianism of possession modus that conquers modern society human. Related to this, Charles Taylor, with reference to Plato emphasises that "a curse of a human that is ruled by their desires is in their inability for content, and in being constantly outstretched by the desires. A desire is, Plato says "by its nature insatiable" (Taylor, 1989:182). This "curse" Taylor describes in his tome Sources of the Self, is a dominant characteristic that arranges habitus of a human of the hyper-consumer society, by hypertrophying the need for possessions and at the same time annulling the need for being. Modern society human models their identity with different consumer models, "at least partially reveals who I am as a unique individual, through the things I buy, and objects that extend my personal and family life, through the signs that I combine »in my own way«. In the time when a tradition, faith and politics are less creators of the central identity, the consumption more and more takes over a new identity function" (Lipovetsky, 2006:28). In that sense the individual shapes their identity in an organised consumer universe whose essential characteristic is embodied in the possession modus. Therefore, the modern society defines its credibility using possession modus, which causes antinomy of what man truly is, their original being and what others want them to be what the market imposes as a desired self-treatment. In such a constellation of conditions, a man is crucified between their inner essence and exterior demands, whereat frequently loses their essential human orientation while trying to gain attention of the exterior. Consumer society creates a "quasi subject" of a languid spirit out of an individual, deprived of feelings and destroyed by boredom, obsessed with elegant consumer exaggerations. While Lipovecky emphasises consumption as a central agent of socialisation in the modern society, analysing modern social trends Fromm introduces the term "marketing character personality" underlining that "the aim of the marketing character is a complete adaptation so as to be desirable under all conditions of the personality market. The marketing character personalities do not even have egos to hold onto, that belong to them, and do not change" (Fromm, 2004:163). The rapidity surrounding the individual and conditions that they live in, do not allow stabilization of habits, but as soon as the habits are accepted the need for innovation is enforced. Modern trends tend to create an eternal child out of an adult, not allowing them to mature, offering the abundance of trivial pleasures and ready-made "recipes" for a comfortable life, thus making the person powerless over the authority force of civilisation products. This practice in terms of hyper consumer society is becoming a necessity that determines the existence, while elusiveness and speed under which the conditions of modern society change and innovate $Z$ Bauman addresses as a liquid life. Emphasising that "Liquid life is consuming life. It casts the world and all its animate and inanimate fragments as objects of consumption: that is, objects that lose their usefulness (and so their lustre, attraction, seductive power and worth) in the course of being used" ( Bauman, 2009:18). Continued changes that with a burden follow the life events of individuals and groups, are seemingly presented as the privilege and necessity, but are actually disguised mechanisms that lure and seduce individuals and groups by easy consumption, while negating indirectly the authenticity of the being. Referring to the consumer society, Veblen uses the terms "conspicuous consumption", "wasteful economy", "deliberate wasting", "individual competition", and "pecuniary 
emulation". Therefore possessing is a primal determinant using which a person evaluates themselves and gains a reputation in the eyes of others. As Veblen realises, even though possessing had always been valued in primitive communities, along with the civilisation progress it "now even more becomes the most easily recognised evidence of a reputable degree of success as distinguished from heroic or signal achievement. It becomes indispensable to accumulate, to acquire property in order to retain one's good name. The possession of goods, whether acquired aggressively by one's own exertion or passively by transmission through inheritance from others, becomes a conventional basis of reputability" (Veblen, 2008:91). Consumption is not only incorporated in everyday life in the domain of a mere existence, it is established in the field of culture, religion, sport, and therefore people present themselves not through their 'self' but through their possessions, i.e. through the extension of their own being imposed by consumer culture. "In the modern community there is also a more frequent attendance at large gatherings (...); in such places as churches, theatres, ballrooms, hotels, parks, shops and the like. In order to impress these transient observers, and to retain one's self-complacency under their observation, the signature of one's pecuniary strength should be written in characters which he who runs may read. (Ibid, 2008:138). A necessity for consumption becomes a custom, and as soon as the well adopted custom becomes incorporated in the fashion of behaviour, it becomes a standard which defines reputability and becomes a condition for acceptance.

Behind this pageant are principles of liberal doctrine that incorporates all elements of the repression and is a worthy rival to the totalitarian mind. Our choice of engaging a credible source came down to a detailed view of Alan Touraine, who says: "that extreme liberalism used to be an avant-garde of modernism but it got off the stage and now creates a type of economic society where the postmodern culture is developed.... As the society more and more resembles to the market without ideological or even political problems, all that remains is a struggle for money or search for identity. Social problems have been replaced by non-social, and individual problems by global problems, that far exceed the social and political sphere, thus destroying much of its content. It is a society that rejects the analysis, which does not believe in great ideas and solemn speeches that disturb its pragmatism and its dreams. The greatest strength of the liberal vision is that it seems to provide the best protection against all attempts of the governing elites to take power, especially those who claim to speak on behalf of mankind and society. Money seems to be the least personal and therefore the least cruel of all masters while people with convictions that include grandiose projects are always trying to impose their religion and their power over others" (Touraine, 2007:148). Completely negating the prospects of humanity, modern civilization creates existentially disoriented individual whose merit of valorisation is trapped in a range of instant pleasures and instant living. Postmodernism is in compliance with the logic of neoliberal capitalism, whose oxymoron is consisted of a hypnotic profit and a consumption lever, reflected as a workflow.

Hermut Krauss, sees postmodernism as a period of undefined paradigm in which performs general cognitive theoretical destruction, within which "antagonistic tensions replace joyous crowd, narration suppresses the law, and the regression of opinions is transformed into a change of paradigms" (Kuljic, 2006: 54). An important support of postmodernism is the fragmentation, as seen from the perspective of the parts, while the whole is unreachable. The idea of the whole is replaced by the idea of the unstable crowd that before managing to evolve, becomes anachronistic or at least has its alternative. Therefore, we live in a world filled with alternatives and possible choices, and again it all comes down to the individual's decision what to choose as their "own" in the range of given opportunities. In addition, the whole or the totality, as well as the reality, remain in the past, and the present promotes the world of virtuality as if "we no longer live in the reality or we oppose it, as well as we handle a multitude of equal realities" (Ibid, 2006:55). From the perspective of Habermas, postmodernism is a phase which deepens the existing and from the existing derives new forms, focusing on the present moment, and neglecting the future. Therefore, whatever happens, happens in the present, and thereby postmodernism lacks historical vertical (according to Kuljuca), because it does not reflect on the past, nor does it direct the perspective to the future. Zygmunt Bauman defines postmodern society as consuming, and modern society as a productive. Thus, modern society socializes its members as producers, while postmodern society prepares them for the role of the purchaser and the consumer. As a metaphor for postmodernism, similar to Baudrillard, Bauman uses the term giant shopping centre: "we can understand postmodernism as a giant shopping centre full of goods whose main function is enjoyment of the shopping itself, the existence that acts like the eternal stay at the shopping centre. This also represents a constant freedom to do whatever we want, along with a constant questioning, what is worth doing, and who should we do it for" (Bauman, 1992:499).

"Faustian Bargain" and panegyrical enthusiasm with postmodern and modern science that uses man as a mere servant, can be found in the words of the liberal doctrine spokesperson Francis Fukuyama. Revising epochal pages of philosophical records of Hegel and Kojève, in the creation of a Universal History and Truth embodied in the liberal doctrine, in his paradigmatically transferable title, dictated in a essentially ideological manner and liberated from gnoseologic standards-settings, in an attempt to glorify liberal democracy, Fukuyama will in the end quite unconsciously, 
anticipate an actual end of mankind, as we can understand his work "The End of History and the Last Man" through a thematic diminutive. Exactly due to a priori condition of social progress is predestined by liberal freedoms, Fukuyama recklessly anticipated a Western man scripture, who is a tactical potential of global production. This systematic manoeuvre is an image of the Western man being, influenced by technological imaginarium or a brainwashing of a kind. In addition it remains to notice Fukuyama's priceless importance, which naturally is in the context of postmodern man cataloging. "The first way in which modern natural science produces historical change that is both directional and universal is through military competition. The universality of science provides the basis for the global unification of mankind in the first instance because of the prevalence of war and conflict in the international system. Modern natural science confers a decisive military advantage on those societies that can develop, produce and deploy technology the most effectively, and the relative advantage conferred by technology increases as the rate of technological change accelerates"(Fukuyama, 1997:97). Fukuyama's explicit voice - secured by the ideological status of technological merit, which votes for the progress, creates and seeks a new identity sphere that would support such a truth as the previously launched framework of postmodernity. In this rapture of images, Fukuyama's manifest cannot be introduced as a credible "paradigm of the time", due to most strictly specified penetrations listed. Using a fatality of a kind, postmodernism ruptures with the mantra of "eternal return" of which modernist myths were speaking. Strongly supporting arguments of "disqualification" of postmodern culture and the search for an adequate time equivalents, Dugin's explicit "message" is that: "postmodernism comparing to modernism, does not have a programme and does not tend to overcome or crash modernism. Postmodernism is deeply indifferent towards modernism values, the whole patois of its critics, the whole tension of the "spiritual Enlightenment". Postmodernism is not active but passive. What is interesting is as follows: during the change of the paradigms - from, modernism to postmodernism - once sunken continents of the "traditional society" emerge, seemingly long time ago outdated and scattered guidelines. Postmodernism - especially of the Third World, but not only there - uses the critical phase of the transition to remind of itself. In this way, no matter how paradoxal it seemed, archaic identities are more and more noticed: in the language of politicology a term "empire" and "empires" (plural); after the centuries of suppression by national states, ethnicities remind of themselves; religions (among other Islam) reappear as the factor of world's real politics, and sects and radical political organisations reproduce parameters of ancient hierarchies. That is how, in our world, evolves a complex mosaic system of the identity" (Dugin, 2009:37). "Geopolitics of Postmodernism" by Aleksandr Dugin, whose lines we quote is an initial reading and historical subtext for the political geography of postmodernism. The author warns that the term "Empire" must be differed from this term used in traditional societies. "Empire in the postmodern context represents a network (nota a spatial) structure. That "empire" does not oppose the "civil society", but practically overlaps with it. It is based on the absolutisation of liberal values and principles, but nowise on the archaic systems of hierarchies. It does not deny but continue the modernism, leading it to a new, quality higher level, without proposing an alternative. That "empire" actually represents a synonym for the globalisation" (Dugin, 2009:39). Theoretical investment of our epistle provides Baudrillard's vision of a well-known Narcissus, who, according to Baudrillard, is not fascinated by his own reflection as a perfect erogenous identity, but as a situation of cancelling the Other. "Bending over a pool of water, Narcissus quenches his thirst. His image is no longer "other"; it is a surface that absorbs and seduces him, which he can approach but never pass beyond. For there is no beyond, just as there is no reflexive distance between him and his image. The mirror of water is not a surface of reflection, but of absorption" (Baudrillard, 1994:75). A post-postmodern individual cannot be a vulnerable narcissus. Their identity must be emphasised by euphoric enjoyment of everyday rhythm of consumer culture. Today's individual is characterised by a statelessness of a kind, banished out of their identity orbit.

\section{References}

Bauman, Z. (1992), Intimations of Postmodernity. London: Routledge.

Bauman, Z. (2009), Fluidni život, Novi Sad: Mediteran publishing.

Bodrijar, Ž. (1993), O zavođenju, Podgorica: Oktoih.

Božović, R.R. (2009), Život kulture, Beograd: Filip Višnjić.

Dugin, A. (2009), Geopolitika postmoderne, Beograd: „Prevodilačka radionica Rosić“ - "Nikola Pašić*.

Fromm, E.(2004), Imati ili biti, Zagreb: Izvori (Biblioteka SAPIENS).

Fukujama, F. (1997), Kraj istorije i poslednji čovjek, Podgorica: CID.

Kuljić, T. (2006), Kultura sjećanja. Beograd: Čigoja

Lipovecki, Ž. (2008), Paradoksalna sreća, Novi Sad: Izdavačka knjižarnica Zorana Stojanovića.

Simić, Ž. (2007), Filozofija moderne psihe (epsitemologija totalitarne svesti-od Dekarta i Paskala do Frojdove ego-koncepcije), Beogard: Kulturno-prosvetna zajednica Beograda.

Simić, Ž. (2012), Uliks i post-postmodern (Filozofija egzistencije nestajućeg subjekta), Beogra: Prosveta. 
Tejlor, Č. (1989), Izvori sopstva, Beograd: Akademska knjiga.

Touraine. A. (2007), Kritika modernosti, Zagreb: Politička kultura.

Vatimo, Đ. (1991), Kraj moderne, Novi Sad: Bratstvo - Jedinstvo.

Veblen, T. (2008), Teorija dokoličarske klase. Novi Sad: Mediteran publishing. 